\title{
Biopsychosocial Factors Affecting Quality of Life in Post-stroke Patients: A Path Analysis Evidence from Surakarta Hospital, Central Java
}

\author{
Maki Zamzam', Didik Gunawan Tamtomo²), Vitri Widyaningsih3) \\ 1)Masters Program in Public Health, Universitas Sebelas Maret \\ 2)Department of Anatomy, Faculty of Medicine, Universitas Sebelas Maret \\ 3)Faculty of Medicine, Universitas Sebelas Maret
}

\section{ABSTRACT}

Background: Basic health research shows that the prevalence of non-communicable diseases has increased, including cancer, stroke, chronic kidney disease, diabetes mellitus, and hypertension. The impact of these changes can cause one of them to decrease the quality of life of patients. Stroke in individuals can cause several changes includeing physical, social and psychological changes that will affect the quality of life. This study aimed to analyze the determinants of the quality of life of patients post stroke.

Subjects and Method: This study was a cross sectional study conducted at Surakarta City Hospital, from September to October 2019. The sample used was 200 patients post stroke. The sampling technique used purposive sampling. The dependent variable was the quality of life of patients post stroke. The independent variables were age, gender, employment status, patient income, family income, attack status, post-stroke comorbidity, duration of illness, marital status, family support, level of functional disorders, and depression status. The data were collected by questionnaire. The data were analyzed by path analysis with the Stata 13 program.

Results: The quality of life of post-stroke patients increased directly in patients with married status $(\mathrm{b}=1.79 ; 95 \% \mathrm{CI}=0.24$ to $3.35 ; \mathrm{p}=0.024)$, have a job $(\mathrm{b}=1.93 ; 95 \% \mathrm{CI}=0.13$ to $3.72 ; \mathrm{p}=$ o.035), good family support $(b=2.17 ; 95 \%$ $\mathrm{CI}=0.46$ to $3.88 ; \mathrm{p}=0.013$ ), and mild functional disorders $(b=1.68 ; 95 \% \quad C I=0.11$ to 3.25 ; $\mathrm{p}=0.036)$. Quality of life decreased directly in patients aged $\geq 60$ years old $(b=-1.99 ; 95 \% \mathrm{CI}=-$ 3.80 to $-0.17 ; \mathrm{p}=0.032)$, female gender $(\mathrm{b}=-1.74$; 95\% $\mathrm{CI}=-3.28$ to $-0.19 ; \mathrm{p}=0.027)$, strokes more than 1 time $(b=-1.87 ; 95 \% \mathrm{CI}=-3.59$ to -0.15 ; $\mathrm{p}=0.033)$, sick $\geq 6$ months $(\mathrm{b}=-2.12 ; 95 \% \mathrm{CI}=-$ 3.87 to $-0.36 ; \mathrm{p}=0.018)$, have comorbidities $(\mathrm{b}=-$ 1.96; 95\% CI=-3.67 to $-0.24 ; \mathrm{p}=0.025)$, and depression $(b=-1.40 ; 95 \% \quad C I=-2.97$ to 0.16 ; $\mathrm{p}=0.078$ ). Quality of life was indirectly affected by age, illness, marital status, family support, family income, and employment status.

Conclusion: The quality of life of post-stroke patients increased directly affected by marital status, employment status, family support, and functional disorders. Quality of life was directly affected by age, gender, attack status, duration of illness, comorbidity and depression.

Keywords: stroke, quality of life, path analysis.

\section{Correspondence:}

Maki Zamzam. Master Program of Public Health Sciences, Universitas Sebelas Maret, Jl. Ir. Sutami 36A, Surakarta, Central Java. Email: makizz477@gmail.com. Mobile: +6281251543935.

\section{Cite this as:}

Zamzam M, Tamtomo DG, Widyaningsih V (2020). Biopsychosocial Factors Affecting Quality of Life in Post-stroke Patients: A Path Analysis Evidence from Surakarta Hospital, Central Java. J Epidemiol Public Healt. 5(1): 1-14. https://doi.org/10.26911/jepublichealth.2020.05.01.01 


\section{BACKGROUND}

Stroke is a disease that attacks the brain and occurs when blood flow to the brain area is blocked. Blockage in the supply of blood and oxygen can cause the nervous system to stop and even die. Organs associated with the nervous system will be difficult or even immovable (National Stroke Association, 2014; Faridah et al., 2019). Several conditions and habits can increase the risk of having a stroke. These conditions and habits are known as risk factors. The more risk factors they have, the more likely a person is to have a stroke. There are several risk factors that are controlled, such as high blood pressure and smoking. Other risk factors, such as age and gender cannot be controlled (NHLB, 2017).

The impact of a stroke that is common after a person has a stroke is a problem on the physical parts such as weakness, numbness, and stiffness. Other physical problems that can occur due to stroke are dysphagia, fatigue (lack of energy or fatigue), foot drop (inability to lift the front of the foot), hemiparesis, incontinence, pain, paralysis or paralysis, seizures and epilepsy, sleep problems, muscle spasms in hands and feet, and vision problems. Stroke also has an emotional impact such as depression and pseudo bulbar affect (PBA), and its impact on the patient's thought process and curiosity, namely aphasia, loss of memory, and vascular dementia (National Stroke Association, 2014).

The impact of stroke on individuals can cause some changes including physical, social and psychological changes. Physical changes that occur include loss of motor function, including paralysis on one side of the body, unable to walk without assistance, decreased tendon reflexes, difficulty swallowing, inability to interpret sensations, decreased visual function and changes in fulfilling the needs of daily activities (Setiawan et al., 2018).
SUBJECTS AND METHOD

\section{Study Design}

This was an observational analytic study with cross sectional approach. This study carried out at Surakarta City Hospital, Central Java, from September to October 2019.

\section{Population and Sample}

The population in this study were post-stroke patients who were treated at the neurological clinic of Surakarta City Hospital. A sample of 200 study subjects was selected by purposive sampling.

\section{Study Variables}

The dependent variable was the quality of life of patients post stroke. Independent variables were age, gender, work status, patient income, family income, attack status, poststroke comorbidity, duration of illness, marital status, family support, level of functional impairment, and depression.

\section{Operational Definition of Variables}

Age was the length of life of a study subject from birth to when the data is collected. The measuring instrument used was a questionnaire. The data scale was continuous and transformed into dichotomous, coded o for $<60$ years old and 1 for $\geq 60$ years old.

Gender was the gender of the study subject post stroke. Biological characteristics seen from outside appearance. The measuring instrument was a questionnaire. The data scale was continuous and transformed into dichotomous, coded $\mathrm{O}=$ male and $1=$ female. Marital status was the status of the study subject at the time of the study interview. The marital status here includes unmarried, widower/widowed and married. The measuring instrument was a questionnaire. The data scale was categorical, coded $\mathrm{o}=$ not married/widower/widowed, $1=$ married.

Employment Status was the status of the study subject that is still working or not working anymore. The main activities done by respondents and earn income from these activities and were still carried out at the time 
of the interview. The measuring instrument was questionnaire. The data scale was categorical, coded $\mathrm{o}=$ not working, $1=$ working .

Family income measured from the income earned by the family of study subjects in one month of work. For Surakarta City, the monthly minimum wage (MW) is IDR $1,802,-$ 700.00 (Department of Labor and Industry, 2018). The measuring instrument used was a questionnaire. The data scale used was continuous and transformed into dichotomous, coded o for $<$ minimum wage and 1 for $\geq$ minimum wage.

Duration of suffering from stroke was the calculation of the duration of suffering from a stroke starting from the beginning in the diagnosis of a stroke by a doctor until the time of data collection. The measuring instrument was a questionnaire. The data scale was categorical, coded $o<6$ months and $1 \geq 6$ months.

Comorbidity post-stroke was comorbidities diagnosed by doctors that arise in poststroke patients. Post-stroke comorbidities studied in this study included hypertension, diabetes mellitus and other diseases which also suffered by the study subjects. The measuring instrument used was a questionnaire. The data scale was categorical, coded $\mathrm{o}=$ none, $1=$ yes.

Attack Status was the history of a stroke suffered by the subject of the study at the time the study was conducted was a stroke for the first time or whether it had been more than once (repeated). The measuring instrument used was a questionnaire. The data was categorical, coded $\mathrm{O}=$ first, $1=$ more than once.

Family support there were 4 domains of family support studied in the form of emotional support, information support, instrumental support and appreciation support. The measuring instrument used was a questionnaire. The data scale was continuous and transformed into dichotomous, coded $\mathbf{O}=$ low, 1 = high.

Level of functional disorders was the degree of functional impairment which was a measure of functional impairment obtained by study subjects after a stroke. The measuring instrument used was a questionnaire. The data scale was continuous and transformed into dichotomous, coded $\mathrm{o}=$ severe, $1=$ mild

Depression Status was a condition of mood disturbance in the elderly in a prolonged manner that generally arises due to loss of hope or feelings of helplessness. The measuring instrument used was a questionnaire. The data scale was continuous and transformed into dichotomous, coded $\mathrm{o}=$ not depressed, 1 = depressed.

Life quality post-stroke was the quality of life possessed by study subjects after a stroke and treatment, both outpatient and inpatient in hospitals. The measuring instrument used was a questionnaire. The data scale was continuous and transformed into dichotomousus, coded $\mathrm{o}=$ poor, $\mathbf{1}=$ good.

\section{Data Analysis}

Univariate analysis was used to describe each dependent and independent variable. Bivariate analysis was used to determine the relationship between age, gender, marital status, employment status, family income status, duration of illness, attack status, comorbidity, family support, functional impairment, and depression to quality of life as measured by the chi-square test. Multivariate analysis was conducted by path analysis model run on Stata 13.

\section{Research Ethic}

This study was conducted based on research ethics, namely informed consent, anonymity, confidentiality, and ethical eligibility. Ethics permission in this study was obtained from the Health Research Ethics Commission Dr. Moewardi, Surakarta, Indonesia, No.1.052/IX/HREC/2019. 


\section{RESULTS}

\section{A.Sample Characteristics}

The sample description described the continuous data in the study variables.
The results of the analysis of the continuous data sample description are shown in Table 1.

Table 1. Description of characteristics of study subjects

\begin{tabular}{llcc}
\hline \multicolumn{1}{c}{ Variables } & \multicolumn{1}{c}{ Criteria } & Frequency (n) & Percentage (\%) \\
\hline Age & <6o years old & 94 & 47.00 \\
& 26o years old & 106 & 53.00 \\
\multirow{3}{*}{ Gender } & Male & 94 & 47.00 \\
& Female & 106 & 53.00 \\
\multirow{2}{*}{ Patients' Education } & 4 & 2.00 \\
& Elementary school & 70 & 35.00 \\
\multirow{4}{*}{ Marital Status } & Junior high school & 119 & 59.50 \\
& Senior high school & 7 & 3.50 \\
\multirow{2}{*}{ Employment Status } & College & 94 & 47.00 \\
\multirow{2}{*}{ Patient's Income } & Not Married/Widowed & 106 & 53.00 \\
& Married & 112 & 56.00 \\
& Not Working & 88 & 44.00 \\
& Working & 100 & 50.00 \\
\hline
\end{tabular}

Table 2. Description of categorical data sample characteristics

\begin{tabular}{llcc}
\hline \multicolumn{1}{c}{ Variables } & \multicolumn{1}{c}{ Criteria } & Frequency & Percentage (\%) \\
\hline Age & <6o years old & 94 & 52.00 \\
Gender & $\geq 60$ years old & 106 & 48.00 \\
\multirow{3}{*}{ Marital Status } & Male & 94 & 47.00 \\
& Female & 106 & 53.00 \\
Employment Status & Not married/widowed & 94 & 47.00 \\
& Married & 106 & 53.00 \\
Family Income & Not working & 112 & 56.00 \\
& Working & 88 & 44.00 \\
Attack Status & Below MW & 97 & 48.50 \\
& Above MW & 103 & 51.50 \\
Comorbidity post stroke & First & 84 & 42.00 \\
& More than once & 116 & 58.00 \\
Duration of illness & None & 94 & 47.00 \\
& Yes & 106 & 53.00 \\
Depression Status & $<6$ Months & 94 & 47.00 \\
\multirow{2}{*}{ Family Support } & $\geq 6$ Months & 106 & 53.00 \\
\multirow{2}{*}{ Functional Disorders } & Not depressed & 102 & 51.00 \\
\multirow{2}{*}{ Quality of Life } & Depressed & 98 & 49.00 \\
& Low & 99 & 49.50 \\
& High & 101 & 50.50 \\
& Severe & 110 & 55.00 \\
& Mild & 90 & 45.00 \\
& Poor & 92 & 46.00 \\
& Good & 108 & 54.00 \\
\hline
\end{tabular}

\section{Univariate Analysis}

Table 2 present univariate analysis data (dichotomous data) from 200 study subjects ob- tained by patients aged $\geq 60$ years old by 104 people (52\%), male gender by 94 (47\%), unmarried/widowed status were 94 people 
(47\%), there were 112 people (56\%) subjects who did not work, family income of study subjects who were under MR were 97 people (48.50\%), stroke status which was more than once were 116 people (58\%), there were 106 post-stroke comorbidities (53\%), 106 people suffered from $\geq 6$ months stroke (53\%), there were 97 depressed (48.50\%), low family support were 99 people (49.50), severe functional disorders were 110 people (55\%), poor quality of life were 92 people (46\%).

\section{Bivariate Analysis}

\section{Table 3. Bivariate analysis of factors related to quality of life}

\begin{tabular}{lcc}
\hline \multicolumn{1}{c}{ Independent Variables } & OR & p \\
\hline Age & 0.09 & $<0.001$ \\
Gender & 0.48 & $<0.001$ \\
Marital Status & 15.92 & $<0.001$ \\
Employment Status & 4.12 & $<0.001$ \\
Family Income & 19.68 & $<0.001$ \\
Attack Status & 0.97 & $<0.001$ \\
Post-Stroke Comorbidities & 0.10 & $<0.001$ \\
Duration of Illness & 0.35 & $<0.001$ \\
Depression Status & 0.07 & $<0.001$ \\
Family Support & 5.77 & $<0.001$ \\
Functional Disorders & 15.09 & $<0.001$ \\
\hline
\end{tabular}

\section{Path Analysis}

Table 4 presents path analysis of the determinant of quality of life. The quality of life of post-stroke patients increased directly affected by marital status, employment status, family support, and functional disorders. Quality of life was directly affected by age, gender, attack status, duration of illness, comorbidity and depression. Quality of life was indirectly affected by age, illness, marital status, family support, family income, and employment status.

The quality of life of post-stroke patients improved in patients with married status $(b=1.79 ; 95 \% \mathrm{CI}=0.24$ to $3.35 ; \mathrm{p}=0.024)$, have jobs $(b=1.93 ; 95 \% \mathrm{CI}=0.13$ to 3.72 ; $\mathrm{p}=0.035)$, good family support $(\mathrm{b}=2.17$; $95 \%$ $\mathrm{CI}=0.46$ to $3.88 ; \mathrm{p}=0.013$ ), and mild functional disorder $(\mathrm{b}=1.68 ; 95 \% \mathrm{CI}=0.11$ to 3.25 ; $\mathrm{p}=0.036)$.
Table 3 showed that marital status $(\mathrm{OR}=$ 15.92; $\mathrm{p}<0.001)$, employment status ( $\mathrm{OR}=$ 4.12; $\mathrm{p}<0.001)$, family income $(\mathrm{OR}=19.68 ; \mathrm{p}$ $<0.001)$, family support $(\mathrm{OR}=5.77 ; \mathrm{p}$ $<0.001)$, and functional disorders (OR= 15.09; $\mathrm{p}<0.001)$ increased the quality of life. Age $(\mathrm{OR}=0.09 ; \mathrm{p}<0.001)$, gender $(\mathrm{OR}=0.48$; $\mathrm{p}<0.001)$, attack status ( $\mathrm{OR}=0.97 ; \mathrm{p}<0.001)$, post-stroke comorbidities $\quad(\mathrm{OR}=0.10$; $\mathrm{p}<0.001)$, duration of illness $(\mathrm{OR}=0.35$; $\mathrm{p}<0.001)$, and depression $(\mathrm{OR}=0.07$; $\mathrm{p}<0.001)$ decreased quality of life. 
Zamzam et al./ Biopsychosocial Factors Affecting Quality of Life Affecting Quality of Life

mily income status $(\mathrm{b}=0.71 ; 95 \% \mathrm{CI}=0.08$ to $1.34 ; \mathrm{p}=0.028$ ) through family support.

There was an indirect relationship between quality of life and employment sta- tus $(b=0.71 ; 95 \% \mathrm{CI}=0.15$ to $1.28 ; \mathrm{p}=0.014)$ through family income.

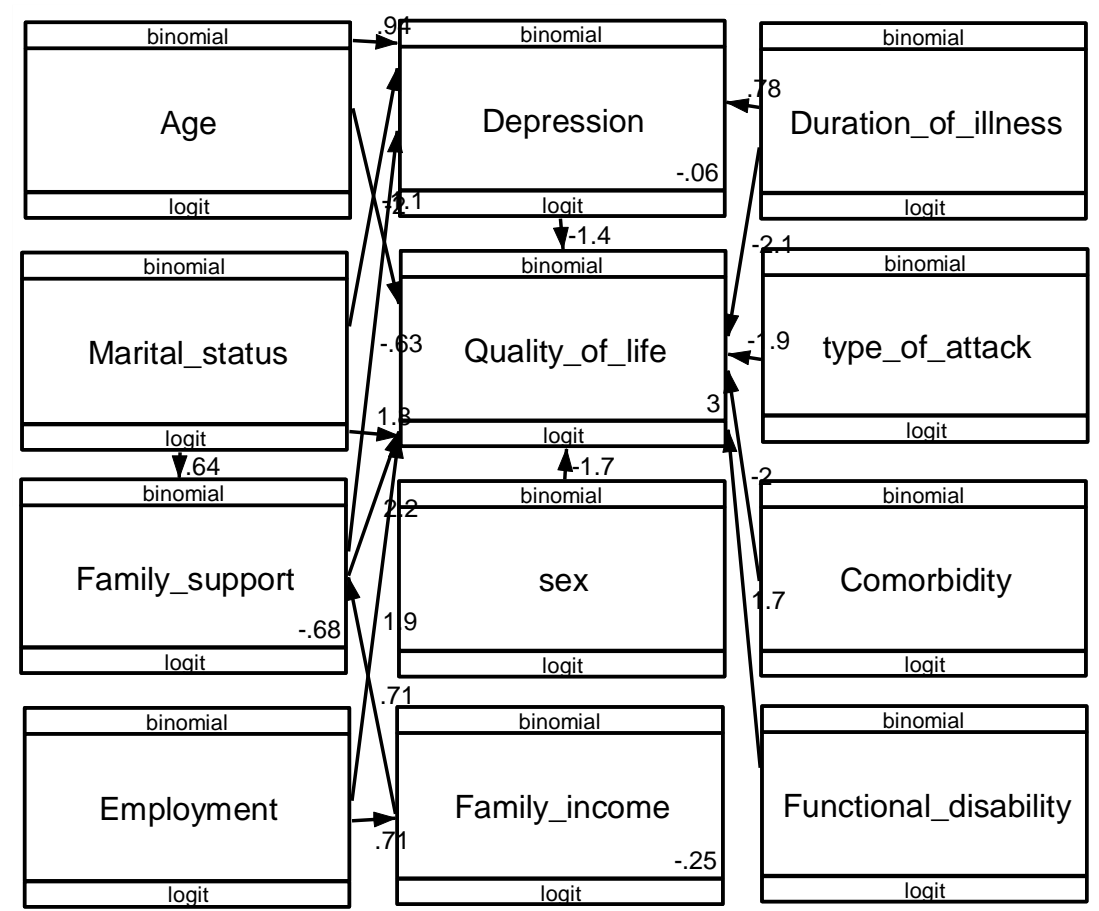

Figure 1. Path analysis model with estimation

Table 4. Path analysis of the determinant of patients' quality of life post stroke

\begin{tabular}{|c|c|c|c|c|c|c|}
\hline \multirow[b]{2}{*}{$\begin{array}{l}\text { Dependent } \\
\text { Variables }\end{array}$} & & \multirow[b]{2}{*}{ Independent Variables } & \multirow[b]{2}{*}{$\mathbf{b}$} & \multicolumn{2}{|c|}{$95 \% \mathrm{CI}$} & \multirow[b]{2}{*}{$\mathbf{p}$} \\
\hline & & & & $\begin{array}{l}\text { Lower } \\
\text { Limit }\end{array}$ & $\begin{array}{l}\text { Upper } \\
\text { Limit }\end{array}$ & \\
\hline \multicolumn{7}{|l|}{ Direct Effect } \\
\hline \multirow{10}{*}{$\begin{array}{l}\text { Quality of Life } \\
\text { (good) }\end{array}$} & $\leftarrow$ & Age ( $\geq 60$ years old) & -1.99 & -3.80 & -0.17 & 0.032 \\
\hline & $\leftarrow$ & Gender (female) & -1.74 & -3.28 & -0.19 & 0.027 \\
\hline & $\leftarrow$ & Marital Status (married) & 1.79 & 0.24 & 3.35 & 0.024 \\
\hline & $\leftarrow$ & Employment Status (working) & 1.93 & 0.13 & 3.72 & 0.035 \\
\hline & $\leftarrow$ & Attack Status (more than 1 time) & -1.87 & -3.59 & -0.15 & 0.033 \\
\hline & $\leftarrow$ & Duration of Illness ( $\geq 6$ months) & -2.12 & -3.87 & -0.36 & 0.018 \\
\hline & $\leftarrow$ & Comorbidity (yes) & -1.96 & -3.67 & -0.24 & 0.025 \\
\hline & $\leftarrow$ & Depression Status (depression) & -1.40 & -2.97 & 0.16 & 0.078 \\
\hline & $\leftarrow$ & Family Support (good) & 2.17 & 0.46 & 3.88 & 0.013 \\
\hline & & Functional Disorder (mild) & 1.68 & 0.11 & 3.25 & 0.036 \\
\hline \multicolumn{7}{|l|}{ Indirect Effect } \\
\hline \multirow{4}{*}{\multicolumn{2}{|c|}{$\begin{array}{l}\text { Depression Status } \\
\text { (depression) }\end{array}$}} & Age $(\geq 60$ years old $)$ & 0.94 & 0.26 & 1.61 & 0.007 \\
\hline & & Duration of illness ( $\geq 6$ months) & 0.78 & 0.07 & 1.48 & 0.031 \\
\hline & & Marital status (married) & -1.12 & -1.79 & -0.44 & 0.001 \\
\hline & & Family support (good) & -0.63 & -1.29 & 0.03 & 0.063 \\
\hline \multirow{2}{*}{\multicolumn{2}{|c|}{$\begin{array}{l}\text { Family support } \\
\text { (good) }\end{array}$}} & Marital status (married) & 0.64 & 0.01 & 1.27 & 0.048 \\
\hline & & Family income (above MW) & 0.71 & 0.08 & 1.34 & 0.028 \\
\hline \multicolumn{2}{|c|}{$\begin{array}{l}\text { Depression Status } \\
\mathrm{N} \text { observation }=200 \\
\text { Log Likelihood }=-401.50\end{array}$} & Employment status (working) & 0.71 & 0.15 & 1.28 & 0.014 \\
\hline
\end{tabular}


DISCUSSION

\section{The effect of age on the quality of life} of post-stroke patients

Age directly affected the quality of life of patients post stroke. Patients aged $\geq 60$ years old have a logodd of good quality of life by 1.99 units lower than patients aged $<60$ years old.

Other studies have also shown that post-stroke patients with poor quality of life were more at risk age which was $\geq 55$ years old compared to age without risk, female gender, and absence of medical rehabilitation (Ningrum and Martini, 2016).

Stroke is more common in patients with an average age of $>55$ years old because physiologically, there were physical changes associated with age, including changes in blood vessels in general, including cerebral blood vessels that become less elastic and plaque buildup in the blood vessels of the brain vessels that last for years. The presence of plaque that occurred in the blood vessels of the brain would disrupt blood circulation to the brain so that the brain would experience metabolic disorders, if it occurred continuously, ischemia and cerebral infarction would occur (Bariroh et al., 2016).

2. The effect of gender on the quality of life of post-stroke patients

The results of the analysis showed that gender directly affected the quality of life of patients post stroke. Patients who were female would decrease their quality of life by 1.74 units lower than male patients.

Study done by Lopez-Espuela et al. (2015) found that women had lower quality of life than men. This was because older women have more severe strokes and lack of family support. Gender was associated with several patterns of health and illness. Compared to men, women tend to express their chronic diseases more easily. Women consistently have more health information than men because of their health role in the family (Rahman et al., 2017).

\section{The effect of marital status on the} quality of life of post-stroke patients The results of the analysis in this study indicated that marital status directly affected the quality of life of post-stroke patients. Patients who were married would have a logodd of quality of life by 1.79 units higher than patients with unmarried/widowed status.

The results of this study were in line with the study of Bariroh et al. (2016) which stated that respondents who have a poor quality of life score were respondents with widowed/unmarried status compared to respondents who have a partner. A better quality of life for the elderly was directly enhanced by strong peer support $(b=0.25 ; p$ $<0.001)$, strong family support $(\mathrm{b}=0.59$; $\mathrm{p}=$ 0.002), mild dementia $(b=1.79 ; \mathrm{p}<0.001)$, and married ( $b=12.73, \mathrm{p}=0.039)$ (Suwarni et al., 2018).

Marital status is a form of support given to improve patient health, partner support was highly needed during the period of treatment both during the hospital or when the patient was at home, with the closeness to the partner, it can have an important effect on the healing process (Wahyuni and Rezkiki, 2015).

\section{The effect of employment status on the quality of life of post-stroke pa- tients}

The results of the analysis found that employment status has a direct influence on the quality of life of patients post stroke. Patients who have jobs would have a good quality of life by 1.93 units higher than patients who were not working.

This study was in accordance with Supraba (2015) who stated that employment has a relationship with quality of life where good quality of life for people who work were 9.81 times greater than people who did not work. 
Stroke can cause individuals to experience physical disabilities and setbacks in the form of limitations in moving due to weakness or paralysis in the extremities of the body, disruption in communication and thinking. In post-stroke sufferers, some of them were able to work again, but the skills they have were different from the ones before they had a stroke (Sinha et al., 2013).

\section{The effect of attack status on the quality of life of post-stroke patients}

The results of the analysis in this study showed that the attack status has a direct influence on the quality of life of patients post stroke. There was an effect of attack status on quality of life. Patients who have had strokes more than once would have the possibility of a good quality of life by 1.87 units lower than patients who have suffered a stroke for the first time.

This study was in accordance with the results of study conducted by Yani (2010) which states that health-related quality of life scores in first-time ischemic stroke patients were higher than recurrent ischemic stroke patients. The study also found significant differences between the average quality of life scores related to health in physical function, physical role, and energy.

Fryer et al. (2016), stated that stroke recurrence can occur due to unhealthy lifestyle factors. In addition, other risk factors that also influence were a history of hypertension, Diabetes Mellitus, cardiac abnormalities and medication irregularities. Disability and death that arise in cases of recurrent strokes was much higher than in cases of first stroke.

\section{The effect of comorbidity on the quality of life of post-stroke patients} The results of the analysis in this study showed that comorbidity has a direct influence on the quality of life of patients post stroke. Patients who were diagnosed with comorbidities would have a good logodd (possibly) good quality by 1.96 units lower than patients who did not have a comorbidity.

The results of this study were in line with the study of Berrigan et al. (2016) which showed that physical comorbidities reduce the quality of life. The total effect of comorbidity can reduce 0.05 points on health quality scores. In this health quality score, the difference of 0.03 was considered clinically important, this would affect the quality of life of patients. This study showed that screening and treatment for comorbidities can cause significant improvements in quality of life and show the importance of being aware of the potential effects of comorbidity itself.

The comorbidities in this study were diabetes mellitus and hypertension which were often associated with poorer quality of life scores. This study showed that additional comorbidities can be specifically related to changes not only in physical function but also in memory and thinking. In general, poststroke patients have comorbidities which can increase the risk of systemic medical complications during stroke recovery. Medical complications often occurred in the first few weeks of a stroke (Mutiarasari, 2019).

\section{The effect of duration of illness on the quality of life of post-stroke patients}

The results of the analysis showed that there was a long period of illness that directly affected the quality of life post stroke. Patients who suffer a stroke for more than 6 months would have a good quality of life by 2.12 units lower than patients who suffer a stroke for less than 6 months.

The results of this study were in line with the study of Hayulita and Sari (2014), which stated that there was a relationship between the duration of illness and the quality of life of patients post stroke. Patients who were sick more than or equal to 6 months would experience a decrease in quality 
of life. Long suffering a stroke would make the patient more desperate for the disease, patients would feel helpless with their conditions even though each patient has a different defense mechanism but they would still find it difficult to deal with stressors from the disease (Handayani and Dewi, 2009).

\section{The effect of depression status on the quality of life of post-stroke patients}

The analysis showed that depression directly affected the quality of life. Patients who were depressed would have a good quality of life by 1.40 units lower than non-depressed patients.

The results of this study were in accordance with Sarfo et al., (2017) who stated that stroke patients with depression showed a greater reduction in physical, psychosocial, cognitive and quality of life compared to those without depression. Depression, education, and income have a direct relationship with quality of life (Prasetyaningsih et al., 2016).

9. The effect of family support on the quality of life of post-stroke patients The analysis showed that family support directly affected the quality of life. Patients with high family support would have a logodd of good quality of life by 2.17 units higher than patients with low family support.

This result was in line with study done by Hamalding and Muharwati (2017) which stated that there was a relationship between family support and quality of life after a stroke. The higher the family support, the better the quality of life of patients post stroke. Family support can be in the form of informational support and appreciation support related to the quality of life of patients post stroke.

Family support included information support and appreciation for the quality of life of stroke patients in the post-acute phase in Wonogiri District. Family support included information about the condition of the patient and appreciation for patients from the family to increase self-confidence so that it can affect their quality of life. Therefore, it can be concluded that there was a relationship between information support and appreciation support with the quality of life of post-acute stroke patients (Rahman et al., 2017)

\section{The effect of functional disorder on the quality of life of post-stroke patients}

The analysis showed that functional disorders directly affected the quality of life of post-stroke patients. There was an effect of functional disorders on quality of life. Patients with mild functional impairment would have a logodd of good quality of life by 1.68 units higher than patients with severe functional disorders.

He et al. (2019) stated that there was a relationship between quality of life and functional disorders, it was explained that functional disorders can affect the main life and all activities in daily life which ultimately affect the quality of life felt by these patients.

Berrigan et al. (2016) stated that functional disorders, depression and symptoms of anxiety, fatigue, and physical comorbidities were associated with decreased quality of life post stroke. Functional disorders most strongly reduce the quality of life, the heavier the functional disorders the worse the quality of life.

\section{The effect of age on the quality of life of post-stroke patients through depression}

The results of the analysis of this study indicated that there was an indirect relationship of age and the quality of life of post-stroke patients through depression. Patients who are older than 60 years old would have a logodd (probability) to experience depression by 0.94 units higher than patients with less than 60 years old. 
This was consistent with a study of Stella (2013) which concluded that there was a statistically significant relationship between old age and the incidence of post-stroke depression. Every increase of 1 year, it would increase the quality of life score by 0.36 . The estimation has controlled the influence of family intimacy as a confounding factor using multiple linear regression analysis.

Vincent et al. (2019) linked anxiety and depression with age. As people get older, there was an increase in anxiety and depression. As the patient ages, airway aging and subsequent parenchyma occurred which contribute to more airway obstruction. Furthermore, shortness of breath accompanied by reduced bodily functions and social activities, fear and depression were increasing. Dependence on others for personal care and loss of interest in pleasurable activities, can worsen with aging resulting in increased feelings of stress and anxiety.

\section{The effect of duration of illness on the quality of life of post-stroke patients through depression}

The results of the analysis in this study indicated that there was an indirect relationship of illness for the quality of life of patients post-stroke through depression. Patients who have suffered a stroke for more than 6 months would have a logodd (probability) of having a depression by 0.78 units higher than patients who have had a stroke for less than 6 months.

The results of this study were in line with study by Hayulita and Sari (2014), which stated that the length of suffering from a stroke would affect a person's condition in accepting his/her physical condition and can lead to depression. It was known that the percentage of depression was higher in poststroke patients who suffer from stroke for $\geq 6$ months (74.3\%) compared to post-stroke patients who suffer from stroke for $<6$ months (35.3\%). There was a significant rela- tionship between the length of stroke and the incidence of depression in post-stroke patients.

13. The effect of marital status on the quality of life of post-stroke patients through depression

The results of the analysis of this study indicated that marital status was not directly related to the quality of life of post-stroke patients through depression. Patients with married status would have a logodd (possibility) of experiencing depression by $\mathbf{1 . 1 2}$ units lower than patients with unmarried/widowed status.

This was in line with the study of Gbiri and Akinpelu (2012) which showed that changes in the status of a better quality of life were found in stroke patients with married status. The existence of motivational and emotional stability in post-stroke patients who have a partner can reduce the incidence of depression which resulted in an increase in the social domain on quality of life.

\section{The effect of family support on the quality of life of post-stroke pa- tients through depression}

The results of the analysis of this study indicated that family support has an indirect relationship to the quality of life of poststroke patients through depression. Patients with high family support would have a logodd (possibility) of experiencing depression by o.63 units lower than patients with low family support.

Study done by Wahyuningsih et al. (2019) stated that the risk of depression was reduced by high income, strong family support, strong social interactions, and strong social support. This was in line with study of Hayulita and Sari (2014) which showed that there was a significant and statistical relationship between family support and the incidence of depression in post-stroke patients. Depression was more common in post-stroke patients who have poor family 
support compared to post-stroke patients who have good family support.

\section{The effect of marital status on the quality of life of post-stroke pati- ents through family support}

The results of the analysis in this study indicated that marital status was not directly related to the quality of life of post-stroke patients through family support. Patients with married status would have a logodd of good family support by 0.64 units higher than patients with unmarried/widowed status.

The results of this study were in line with study conducted by Baumann et al. (2012) which stated that respondents who were married had a better quality of life compared to respondents who were not married (widower/widowed). Marital status is a form of social support for stroke patients, because life partners can provide support to carry out healthy and positive life behaviors (Ardi, 2011).

\section{The effect of family income on the quality of life of post-stroke pati- ents through family support}

The results of the analysis in this study indicated that family income have an indirect relationship to post-stroke quality of life through family support. Patients with a family income status above the MW would have a logodd of good family support by 0.71 units higher than patients with a family income which was below the MW.

Sunarti (2013) stated that the economy has always been an important aspect of family life. As income increased, the ability of individuals to meet financial needs also increased. Economic pressure caused by spending greater than income and debt. This high economic pressure can cause unhappy family life. With the family income status above the MW, the fulfillment of daily needs would be better and it can also increase family support.
17. The effect of employment status on the quality of life of post-stroke patients through family income

The results of the analysis in this study indicate that patient's employment has an indirect relationship to quality of life poststroke through family income. Patients with working status would have a logodd of family income above the MW by 0.71 units higher than patients without employment status.

Study done by Rahman et al. (2017) showed that work can help the family's financial condition, while working can help in the direction of physical recovery, increase selfconfidence and reduce depression and improve the quality of life of patients post stroke. Stroke sufferers with low economic level have lower quality of life compared to stroke patients with high economic status. Economic status is very important because it can help to reduce depression that arised in stroke patients (Jun et al., 2015).

\section{AUTHOR CONTRIBUTION}

Maki Zamzam as the main author has roles in carrying out study, collecting study data, formulating study articles, and processing the data. Didik Gunawan Tamtomo has a role in the formulation of the framework of study. Vitri Widyaningsih has a role in the formulation of study methods and discussion of study results.

CONFLICT OF INTEREST

There was no conflict of interest in this study.

\section{FUNDING AND SPONSORSHIP}

The source of funds in this study used personal funds from the main author.

\section{ACKNOWLEDGEMENT}

Acknowledgments were conveyed by author to the Surakarta City Hospital for allowing this study to be carried out. Thank you to all patients who have been willing and cooperative to be the subject of study. 


\section{REFERENCE}

Anggraini S (2016). Correlation between depression level and quality of life of poststroke patients in neurological clinic Panembahan Senopati Hospital, Bantul. Retrieved from http://repository.unjaya.ac.id/id/eprint/642wnload/pdf/12352316.pdf.

Ardi M (2011). Analysis of the relationship between physical and cognitive disability with hopelessness in stroke patients in Makassar (Universitas Indonesia). Retrieved from http://lib.ui.ac.id/file?file=digital/20281864-TMuhammad Ardi.pdf.

Bariroh U, Susanto HS, Adi MS (2016). Quality of life based on characteristics of post-stroke patients (Study at Tugurejo District Hospital Semarang). Jurnal Kesehatan Masyarakat (e-Journal), 4(4): 486-495. Retrieved from https://ejournal3.undip.ac.id/index.php/$\mathrm{jkm} /$ article/view/14276/13808.

Baumann M, Lurbe K, Leandro ME, Chau N (2012). Life satisfaction of two-year post-stroke survivors: Effects of socioeconomic factors, motor impairment, newcastle stroke-specific quality of life measure and world health organization quality of life - bref of informal caregivers in Luxembourg and a rural area in Portugal. Cerebrovasc Dis 33(3): 219230. https://doi.org/10.1159/o00333408.

Berrigan LI, Fisk JD, Patten SB, Tremlett H, Wolfson C, Warren S, Fiest KM, et al. (2016). Health-related quality of life in multiple sclerosis: Direct and indirect effects of comorbidity. Neurol, 86(15): 1417-1424. https://doi.org/10.1212/WNL.0000000000002564.

Department of Labor and Industry (2018). Decree of Central Java MW in 2018. Retrieved from http://www.bloranews.com/wpcontent/uploads/2018/11/S
K-UMK-Jateng-Tahun-2019.pdf.

Faridah U, Sukarmin S, Murtini S (2019). Effect of tilted position on pressure sores in stroke patients in the soewondo hospital area. Jurnal Ilmu Keperawatan dan Kebidanan, 10(1): 155-162. Retrieved from https://ejr.stikesmuhkudus.ac.id/index.php/jikk/article/view/632/385.

Friedman (1998). Family nursing. Jakarta: EGC.

Fryer CE, Luker JA, Mcdonnell MN, Hillier SL (2016). Self management programmes for quality of life in people with stroke. Cochrane Database Syst. Rev, 22(8): CDo10442 https://doi.org/10.1002/14651858.CDo10442.pub2.

Gbiri CA, Akinpelu AO (2012). Quality of life of nigerian stroke survivors during first 12 months post-stroke. Hong Kong Physiother J. 30(1): https://doi.org/10.1016/j.hkpj.2012.01.004.

Hamalding, H. (2017). Relationship of family support with quality of life in the incident of stroke. Jurnal Kesehatan Masyarakat, 7(2): 146-152. http://dx.doi.org/10.31934/promotif.v7i2.88.

Handayani DY, Dewi DE (2009). Analysis of the quality of life of patients and families after a stroke (with sequelae). Psycho Idea, 7(1): 35-44. https://doi.org/10.1521/suli.2008.38.6.699.

Hayulita S, Sari DR (2014). Factors related to depression in post-stroke patients in outpatients in the Bukittinggi National Stroke Hospital (RSSN) in 2014. Yasri Sumbar, Retrieved from http://ejournal.stikesyarsi.ac.id/index.php/JAV$1 \mathrm{~N} 1 /$ article/download/32/123.

He JA, Antshel KM. Biederman, Joseph F, Stephen V (2019). Do personality traits predict functional impairment and quality of life in adult ADHD? A Controlled Study. J Atten Disord, 23(1): 12-21. doi: $10.1177 / 1087054715613440$. 
Jun HJ, Kim KJ, Chun IA, Moon OK (2015). The relationship between stroke patients' socio-economic conditions and their quality of life: The 2010 Korean community health survey. J. Phys. Ther., 27(3): 781-784. https://doi.org/10.1589/jpts.27.781.

Lopez-Espuela F, Zamorano JDP, RamírezMoreno JM, Jiménez-Caballero PE, Portilla-Cuenca JC, Lavado-García JM, Casado-Naranjo I (2015). Determinants of quality of life in stroke survivors after 6 months, from a comprehensive stroke unit: a longitudinal study. Biological research for nursing, $17(5): 461-$ 468. https://doi. org/10.1177/1099800414553658.

Mutiarasari D (2019). Ischemic stroke: symptoms, risk factors, and prevention. Jurnal ilmiah kedokteran, 1(2): 36-44. Retrieved from http://jurnal.untad.ac.id/jurnal/index.php/MedikaTadulako/ article/download/12337/9621.

National Stroke Association (2014). What is stroke? - national stroke association. Retrieved June 13, 2019, from 2014 website:https://www.stroke.org/under stand-stroke/what-is-stroke/.

NHLB (2017). National heart, lung, and blood institute: stroke. Academic radiology, 16(9): e163-e177.https://doi.org/10.1016/j.acra.2009.11.002.

Ningrum DAS, Martini S (2016). Quality of life status 2 years post stroke. Jurnal Ilmiah Kesehatan Media Husada, 5(2): 59-72. https://doi.org/10.33475/jikmh.v5i2.128.

Prasetyaningsih RH, Indarto D, Akhyar M (2016). Association of determinant factors on bio-psychosocial with quality of life in elderly. Journal of epidemiology and Public Health, 01(02): 108-117. https://doi.org/10.26911/jepublichealth.2016.01.02.04.

Rahman R, Dewi FST, Setyopranoto I (2017).
Family support and quality of life for stroke patients in the post-acute phase in Wonogiri District. Berita kedokteran masyarakat, 33(8): 383. https://doi.org/10.22146/bkm.22599.

Sarfo FS, Jenkins C, Singh A, Owolabi M, Ojagbemi A, Adusei N, Ovbiagele B, et al. (2017). Post-stroke depression in Ghana: Characteristics and correlates. J. Neurol. Sci, 379: 261-265. https://doi.org/10.1016/j.jns.2017.06.032.

Setiawan ID, Trisyani Y, Lumbantobing VBM (2018). Life experience of post-stroke patients in Bandung. Retrieved from https://www.researchgate.net/publication/328459269_PENGALAMAN_HID UP_PASIEN_PASCA_STROKE_DI_B ANDUNG_The_Life_Experiences_of_ PostStroke_Patients_In_Bandung.

Sinha AGK, Dhamija D, Bindra S (2013). Functional status and disability in stroke survivors of north india. Indian $\mathbf{J}$ Physiotherapy and Occup Ther, 7(3): 240-244. Retrieved from http://www.ischolar.in/index.php/ijpot/article/view/42903.

Stella P (2013). The relationship between old age and the incidence of depression in post-stroke in Dr. Moewardi Hospital. Retrieved from https://eprints.uns.ac.id/15092/.

Sunarti E (2013) Family safety. Bogor: (ID): IPB Press.

Supraba NP (2015). The relationship of social activities, social interactions, and family functions with the quality of life of the elderly in the Work Area of the Health Center I of North Denpasar, Denpasar City. Retrieved from http://erepo.unud.ac.id/8304/.

Suwarni S, Soemanto R, Sudiyanto A (2018). Effect of dementia, family support, peer support, type of residence, and marital status on quality of life of the elderly in surakarta, central java. journal of epi- 
demiology and public health, $03(01)$ : 83-94. https://doi.org/10.26911/jepublichealth.2018.03.01.07.

Vincent A, Dangi A, Deo M (2019). Prevalence of anxiety and depression in copd patients and its correlation with age, gender, disease severity and health related quality of life | Vincent | Int J Recent Sci. Res. 8(3): 20-22. Retrieved from http://worldwidejournals.net/index.php/IJSR/article/view/92

Wahyuni A, Rezkiki F (2015). Empowerment and self-efficacy of patients with coronary heart disease through structured health education. Jurnal Ipteks Tera- pan, 9(1): https://doi.org/10.22216/jit.2015.v9i1.26.

Wahyuningsih CS, Subijanto AA, Murti B (2019). Logistic regression on factors affecting depression among the elderly. J Epid Public Health, 4(3): 171-179. https://doi.org/10.26911/jepublichealth.2019.04.03.03.

Yani FIA (2010). Differences in health-related quality of life scores between first and recurrent ischemic stroke patients. Universitas Sebelas Maret. Retrieved from https://core.ac.uk/download/pdf/12352316.pdf 